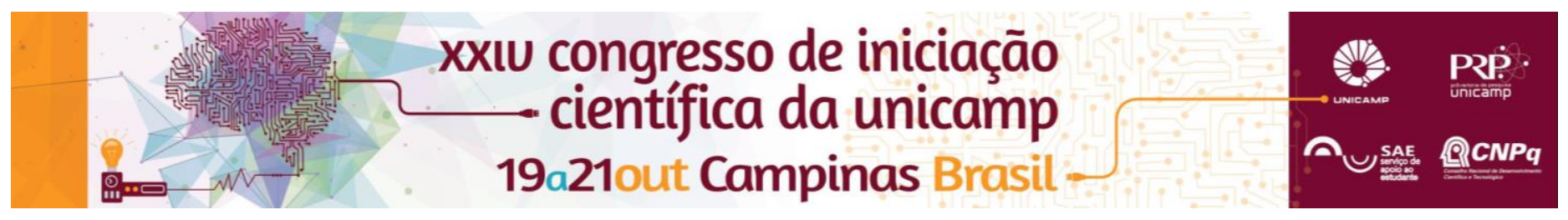

\title{
ANÁLISE EXPERIMENTAL DE BLOCOS DE CONCRETO PRODUZIDOS COM AGREGADOS LEVES
}

\author{
Vanessa F. Roche Pereira*, Rosa C. Cecche Lintz
}

\section{Resumo}

Esta pesquisa trata do estudo de blocos de concreto, substituindo-se parte dos agregados convencionais por agregados leves como: argila expandida e resíduos de borracha proveniente de pneus inservíveis. A moldagem dos blocos foi realizada em máquina mecânica e estes foram submetidos a ensaios de resistência à compressão e absorção de água.

\section{Palavras-chave:}

Materiais Alternativos, Reciclagem de resíduos, Materiais de construção..

\section{Introdução}

A alvenaria estrutural é um dos sistemas construtivos mais antigos existentes. O sistema utilizando blocos de alvenaria, cerâmicos ou de concreto, com função estrutural agrega rapidez e praticidade aos canteiros de obras ${ }^{1}$.

Considerando as reservas naturais disponíveis e a poluição gerada na extração de recursos naturais utilizados na construção civil, deve-se priorizar e integrar a possibilidade de reaproveitamento e utilização de materiais reciclados ou de menor impacto ambiental nas misturas para a fabricação de blocos de concreto. Dessa forma foram estudados blocos de concreto com agregados leves recicláveis.

\section{Resultados e Discussão}

Foram moldados e testados seis traços de referência diferentes até que um deles se encaixou nas exigências das normas ${ }^{2,3}$ ABNT NBR 6136/2014 e NBR 12118/2013. Foi realizada a separação e pesagem dos materiais, moldagem dos traços de concreto em betoneira de eixo inclinado e moldagem dos blocos em máquina mecânica. $\mathrm{Na}$ realização da moldagem foram encontradas algumas dificuldades na operação da máquina. Dependendo de como era manuseado e colocado o concreto nos moldes, os blocos saiam diferenciados. Após a moldagem, os blocos foram curados por 28 dias e capeados para ensaio de compressão.

O traço que apresentou maior resistência a compressão e absorção dentro dos limites estabelecidos pela norma foi o escolhido para pesquisa de substituição dos agregados convencionais por agregados leves $(5 \%$ de massa de pedrisco por argila expandida e $5 \%$ de massa de pó de pedra por borracha). Ambos os resultados foram avaliados aos 28 dias para comparação com o traço de referência.

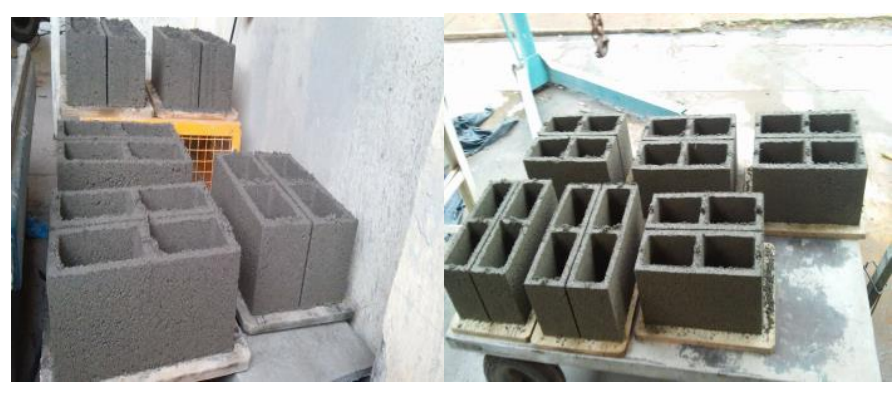

Figura 1: blocos de concreto moldados no laboratório de materiais da FT-UNICAMP

\section{Conclusões}

Foi necessária a moldagem de vários traços para a obtenção de um mais adequado à pesquisa $e$ atendimento às normas. Fica explícito que sem o uso do aditivo plastificante, o concreto para a fabricação dos blocos não chegaria na consistência exata para a moldagem dos mesmos. No momento aguarda-se os 28 dias de cura dos blocos com substituição de agregados para a execução de ensaios de compressão e absorção para que sejam comparados com o traço de referência.

\section{Agradecimentos}

Agradeço a minha orientadora Rosa C.C. Lintz e aos técnicos do laboratório de materiais de construção da FTLIMEIRA.

${ }^{1}$ MICHEVIZ ET AL. (2011). Análise experimental de blocos de concreto com função estrutural produzidos com agregados leves. UNIVERSIDADE TECNOLÓGICA FEDERAL DO PARANÁ, Curitiba- PR.

${ }^{2}$ Associação Brasileira de Normas Técnicas (2013). NBR 12118 - Blocos vazados de concreto simples para alvenaria- método de ensaio.

${ }^{3}$ Associação Brasileira de Normas Técnicas (2014). NBR 6136 - Blocos vazados de concreto simples para alvenaria- requisitos. 